\title{
Takeover as a Form of Corporate Conflict and the Process of Transfer of Stock Ownership's Rights
}

\author{
I.Yu. Belayeva ${ }^{1}, O . V$. Danilova $^{1}$, and K.V. Uskov ${ }^{1, *}$ \\ ${ }^{1}$ Financial University under the Government of the Russian Federation, Moscow, Russia
}

\begin{abstract}
The article considers the problem of corporate conflicts in the Russian practice of corporate relations in the joint-stock companies. Today, corporate relations are changing, the role of intangible resources is growing, and a $100 \%$ share in the company capital does not always guarantee control over the company. In this regard, the range of ways to acquire corporate control is expanding. The purpose of the article is to develop a classification of the methods of joint stock companies takeovers. The proposed classification differs from existing classifications by differentiating takeover methods according to the criterion "takeover tool used by the takeover initiator". The use of this classification by companies in the development of protective mechanisms against takeovers will make it possible to choose the most appropriate and effective protective measures in a particular situation and thereby avoid some corporate conflicts.
\end{abstract}

Keywords: Corporate conflicts; Corporate relations; Takeover; Property relations; Takeover methods; Property

\section{Introduction}

A corporation can be defined as a social system that operates in the economics field of and in the resource exchange field of. Corporate relations in such social systems arise on the initiative of potential participants in corporate relations (stakeholders) at the moment when they have the intention to obtain resources through interaction with the corporation.

The reason for the emergence of corporate relations is the subjective assessment of the stakeholder (potential stakeholder) about the possibility of obtaining benefits from interaction with the corporation, with its other stakeholders. The benefits of a stakeholder should be understood as the resources that the corporation provides him. They should be valuable to the stakeholder, should be able to directly or indirectly satisfy his interests. That is, corporate relations - relations between participants in the economic exchange of resources within the corporation in accordance with the rules and regulations in force in the corporation, which are determined by the institutional environment.

If the expected benefits of the stakeholder are equal to the benefits received, then in this case the activity associated with the impact on the corporation will be low. But if the real benefits and the expected ones do not match, then the stakeholder (or potential stakeholder) can begin to influence the corporation and create the conditions under which it will receive

*Corresponding author: KVUskov@fa.ru 
the expected benefits, including, for example, attempting to redistribute control over property. This means that it will impact the corporation and / or its stakeholders. Thus, corporate relations arise as a result of the activity of potential participants in corporate relations, which, in turn, arises as a result of their interest in obtaining benefits from interaction with the corporation.

Of particular importance to the corporation are "key participants in corporate relations" (key stakeholders). Key stakeholders include individuals and legal entities that own key resources necessary for the smooth operation of the corporation, and also have the ability to have a significant impact on it. Key resources can be not only financial resources or the prevailing share in the authorized capital. Today, stakeholders influence corporations, even without ownership of shares or shares in the authorized capital. There are informal channels of influence, informal leaders who, although they have a great influence on the distribution of resources, are not taken into account by modern means of displaying the state of the company. That is, it is potentially possible to control the activities of the company without the right to property, it is enough to own key resources. In this regard, corporate relations are currently changing, they are being transformed, this affects the features of property management, and the transformation of property theory is also taking place.

In the case when stakeholders do not receive the necessary benefits from interacting with the company, this negatively affects corporate relations, which can lead to a redistribution of areas of influence on the corporation and lead to a redistribution of property rights.

One of the most common forms of corporate conflicts is a takeover, when a participant in corporate relations (a potential participant in corporate relations) seeks to acquire ownership rights. In other words, in the aspect of a takeover, corporate conflicts contribute to the transfer of rights to joint-stock property against the will of the current owners. These can be conflicts between large owners, when one of them seeks to gain corporate control, between current owners and external entities.

Analysis of scientific work in this area $[1 ; 2 ; 3 ; 4 ; 5 ; 6 ; 7]$ allowed to form the following classification of external entities that implement acquisitions (takeover entities):

- competitors whose goal is to gain a larger market share;

- corporations, forming a vertically integrated holdings;

- investment companies whose goal is to resell the target corporation;

- specialized companies that provide takeover services;

- individuals (their motivatopn may differ, but, as a rule, their goal is to acquire a larger share in the authorized capital and get more control).

The implementation of a takeover can have both positive and negative consequences. This is always a negative moment for the current owner, who against his will loses control of the business and actually loses the company. In the case of an inefficient company that infringes on the rights of minority shareholders, a takeover can be a positive moment, so the new owner can improve the situation in the company and increase its capitalization.

The purpose of the article is to develop a classification of takeover methods of the jointstock companies.

Tasks:

- analyze the main methods to acquire corporate control rights in Russia (analysis of scientific papers in this field);

- develop a general term related to the transfer of corporate control rights -«takeover»

- identify the typical takeover stages in the Russian practice. 


\section{Methodology}

As research tools, such general scientific methods as systemic, factorial, functional, and comparative analysis were used. The study analyzed scientific papers in the field of organizing protection against threats from the mergers and acquisitions market; the practice of acquiring corporate control in Russia; practice of organizing protection against takeovers. An analysis of the main takeover methods in Russian practice was carried out. This allowed us to develop a classification of the takeover methods, which differs from the existing classifications by differentiating the takeover methods according to the criterion "takeover tool used by the takeover initiator".

Initially, we analyzed the processes of transition of rights to corporate control (forms of corporate conflicts) that exist in Russian economic practice and are covered in the scientific literature. There are many processes that are similar in essence, but have different names, including "unfriendly takeover", "hostile takeover", "corporate takeover", and "corporate raid". These processes were analyzed in the works of Arutyunova K. G., Burykin D. V., Gomtsyan S. V., Iontsev M. G. Krichevsky N., Radygin A.D., Savchuk S., Sogrina D. V., Trifonova L. A., Etnov R. M. There was an idea to define a General term. The term "takeover" was chosen and the author's definition was given.

Takeover - actions of one and (or) several individuals (legal entities) aimed at acquiring rights to corporate control in the face of resistance from the majority of the company's owners. Various processes of transition of rights to corporate control were considered. We considered how the takeover subject gets control over the property, what algorithm of actions it performs. Similar points were identified when implementing different methods of acquiring corporate control rights, and a new classification was developed, which is described below.

\section{Results}

As a result of the analysis of modern Russian practice of acquiring control over corporations, as well as existing research in this area, a classification of takeover methods of joint stock companies has been developed (picture 1).

1. Takeover methods, the implementation of which is carried out in the framework of the right field.

1.1. The takeover method, the implementation of which is carried out through the shares of the target corporation:

1.1.1. Direct shares buying.

The condition for the implementation of the takeover method is the consent of the shareholders to sell their shares. However, such consent may be forced, and this must be taken into account.

There are several options for implementing this takeover method.

Option 1 - buying of a minimum controlling block of shares which is consolidated by a major shareholder or a group of shareholders of the target company. In this case, the takeover entity is able to make strategic decisions [1, p. 67].

This option provides 2 situations:

- the controlling shareholder (group of shareholders) voluntarily sells shares;

- the takeover entity forces the controlling shareholder (group of shareholders) to sell the shares.

Option 2 - buying of a minimum controlling block of shares which is consolidated by minority shareholders. This option is common in companies with dispersed share capital. The disadvantage of using this option can be considered a situation in which the demand for 
shares of the target company increases. Thus, obstacles are created to complete the transaction. The problem will be more significant when the threshold value of the control packet is high [1, p. 11-12]. Russian corporations are characterized by a low dispersed share capital, as a rule, a small number of owners.

Option 3 - buying of fewer shares than a controlling stake. Typically, this option is implemented with the aim of making decisions with the goal of forcing the remaining shareholders to sell their shares of the target corporation.

1.1.2. The purchase of votes of minority shareholders of the target corporation.

The purchase of votes is a way of gaining control over a corporation, used mainly in the United States. It is realized in the form of purchase of votes of minority shareholders and is an expensive takeover method. The purchase of votes takes place immediately before the general meeting of shareholders. The trustee receives from minority shareholders the right to vote on certain issues independently. The main purpose of the purchase of votes of shareholders is to change the composition of the board of directors of the target company [1, p. 11]

With the successful implementation of this takeover method, the takeover subject gets the opportunity to influence the decision-making process on the board of directors through its representatives. For example, this may be a change of management, sale of assets, changes in the internal documents of the company. The purchase of the votes of minority shareholders may also force the controlling shareholder to sell his shares.

A prerequisite for the effective implementation of this takeover method is the consolidation of 30 or 50 percent of the voting shares of the target company for voting.

In addition to acquiring the votes of minority shareholders, the acquisition entity may initiate shareholder agreements. Such agreements are concluded to achieve an agreed position in the voting process at the general meeting of shareholders.

1.2. Impact on stakeholders of the target corporation.

The aim of implementing this takeover method is to obtain the support of stakeholders in the process of acquiring control over the corporation. That is, the absorption entity in this case seeks to influence the actions and decisions of stakeholders.

Successful implementation of the takeover method will create conditions for influencing strategic decisions (if there is support from board members, managers, shareholders). In addition, the takeover entity may indirectly impede the company's activities (if there is support from creditors, suppliers, key customers, registrar, employees, etc.). 


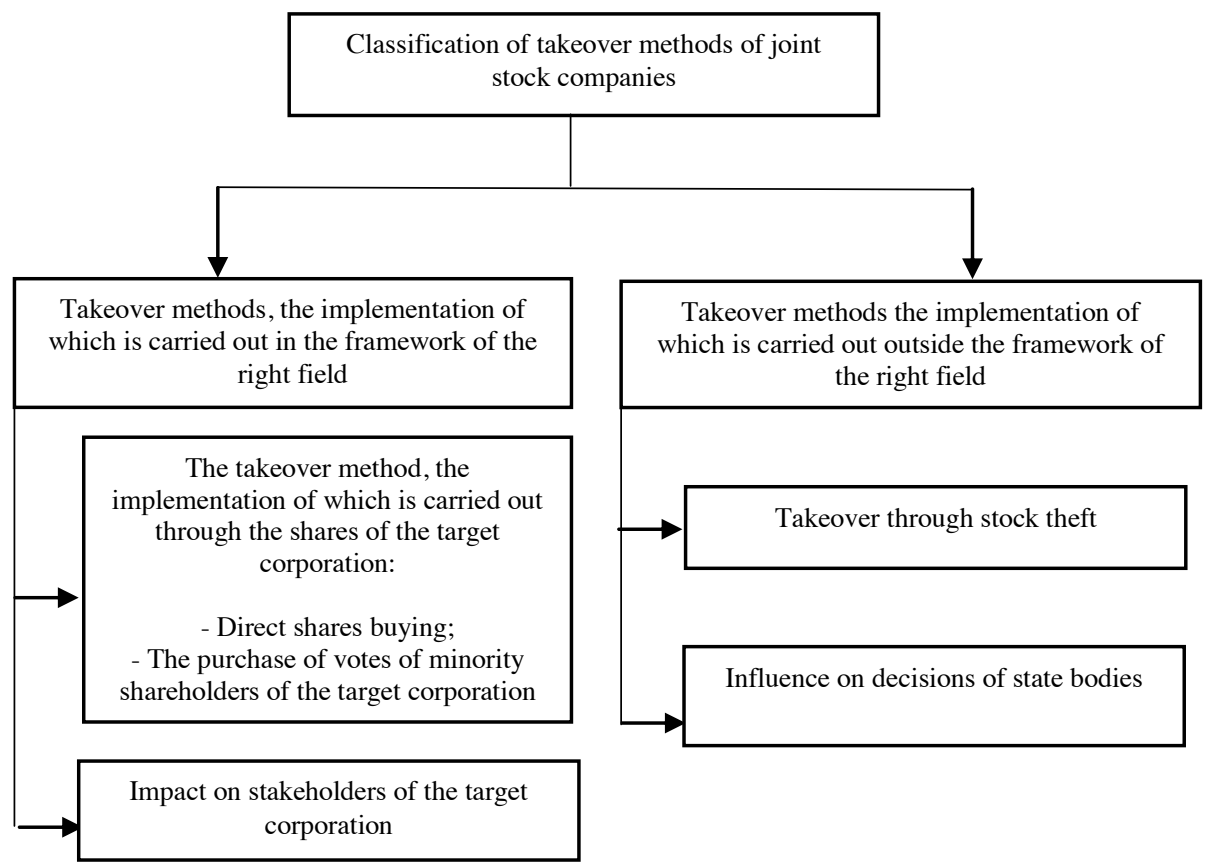

Fig. 1. Classification of takeover methods of joint stock companies Source: Own processing.

Since the takeover is also realized through the bankruptcy of the target corporation, in this case the takeover entity either acquires the company's debts or stimulates the initiation of bankruptcy proceedings by its lender (that is, the lender acts in the interests of the takeover entity).

The existence of such takeover method forces corporations to organize high-quality interaction with stakeholders. They need to ensure the loyalty of at least key stakeholders, create conditions for long-term mutually beneficial cooperation. If this is achieved, the stakeholder will not contribute to the takeover entity and this will ensure the preservation of ownership for current shareholders.

Today, one of the most important factors affecting the modification of corporate relations is the loyalty of stakeholders.

There are many Russian and foreign studies of the concept of "loyalty", and it is understood differently [8]. Typically, loyalty is associated with the loyalty of only staff, customers, and the theoretical basis on this issue is mainly related to marketing.

In scientific papers, it is noted that loyalty has a positive effect on the quality of work of employees and their behavior, increases their responsibility, reduces the risks of their leakage, contributes to a more efficient functioning of the corporation, and increases its stability.

The presence of similar concepts of loyalty, difficulty in developing its diagnostic tools, problems with a clear definition of loyalty factors are the reasons that give loyalty to a corporation the status of a problem [9, p. 3].

Loyalty is associated with such characteristics of a stakeholder as benevolence, honesty, friendliness, openness, integrity, loyalty, devotion, acceptance of company values [8].

Loyalty should be considered not only in relation to internal, but also to external stakeholders of the corporation. Today, relations between companies and stakeholders in 
terms of social responsibility are becoming important, and external stakeholders play a special role here.

The analysis of scientific works in this subject area made it possible to develop a generalized interpretation of the term "stakeholder loyalty". Stakeholder loyalty is a characteristic of a stakeholder indicating a high probability of a positive attitude towards the corporation and a high probability of useful behavior within it.

A loyal stakeholder is ready to lose his resources (that is, to make concessions for the benefit of the company and to the detriment of himself) and to cooperate with the company for a long time.

Factors affecting stakeholder loyalty include "actual stakeholder satisfaction from engaging with the corporation"; "future satisfaction from engaging with the corporation"; "the impact on the stakeholder of the institutional environment of the corporation", as well as "the ability to obtain the same (or more valuable) resources outside the corporation" (for example, when interacting with other corporations) (picture 2).

The actual satisfaction of the stakeholder from interacting with the corporation is affected by expectations in obtaining resources, as well as the actual resources received by the corporation. Expectations are formed on the basis of the interests of a stakeholder, the share of his resources in a corporation, and the value of resources. With increasing stakeholder satisfaction from interacting with a corporation, its loyalty increases.

The stakeholder's satisfaction in the future is affected by the history of his relationship with the corporation (the results of relationships that can be both positive and negative), his attitude to the history of relations with the corporation of other stakeholders, and the duration of his cooperation with the corporation. The subjective assessment of the stakeholder about the high probability of obtaining the resources he needs from cooperation with the corporation in the future increases loyalty.

The influence of the institutional environment of a corporation on a stakeholder consists in the influence of social institutions that transmit loyal behavior, as well as in the actions taken by a stakeholder [10, p. 213]. The term "social institution" in the framework of this study is understood as an information object, which reflects the forms of behavior and their consequences. The stronger the influence of social institutions that broadcast loyal behavior, the higher the stakeholder loyalty.

The possibility of obtaining similar (more valuable) resources outside the corporation depends on factors such as the availability of cooperation proposals from the takeover entity, as well as the availability of cooperation proposals from other corporations $[10, \mathrm{p}$. 213]. With such offers, stakeholder loyalty could potentially decrease. 


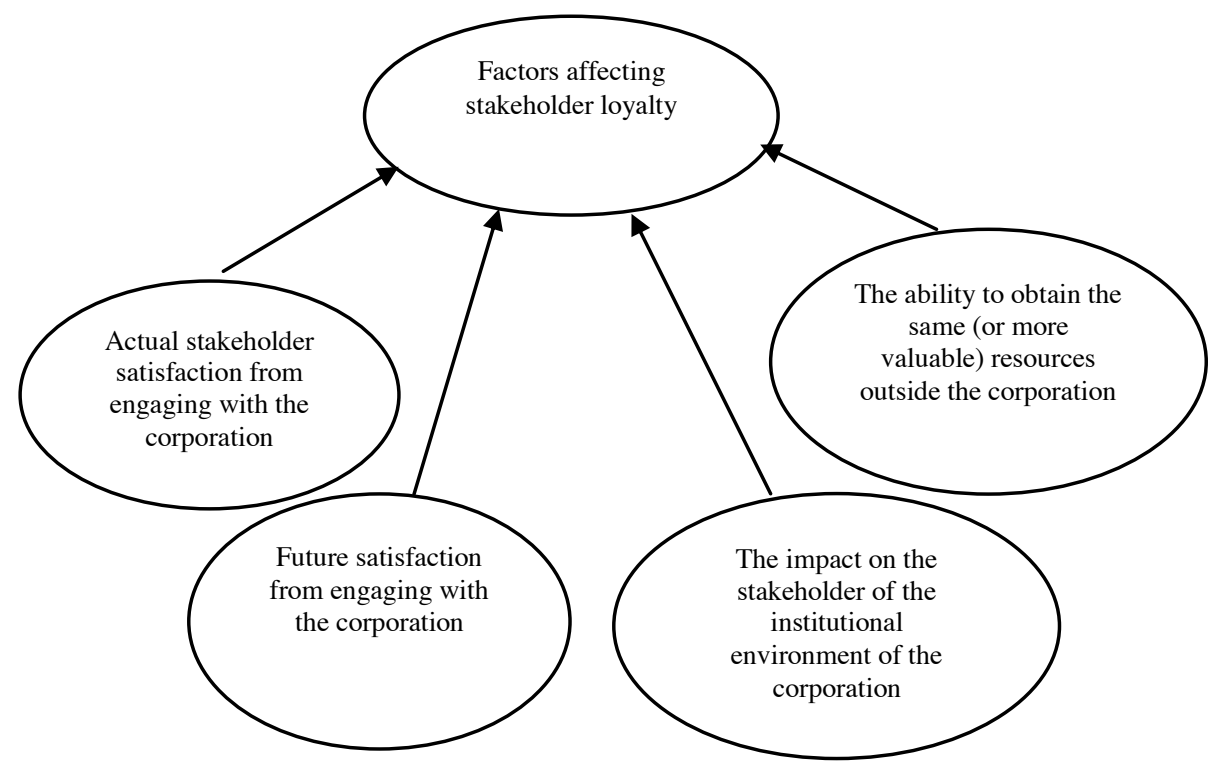

Fig. 2. Factors affecting stakeholder loyalty Source: Own processing.

It is also worth noting that psychological characteristics affect loyalty. Next, we should consider the takeover methods, the implementation of which is carried out outside the framework of the right field.

2. Takeover methods the implementation of which is carried out outside the framework of the right field.

2.1. Takeover through stock theft.

When embezzlement of the shares of the target corporation, the entity takes actions outside the legal framework, and these actions are classified as a crime. All methods of stock theft can be generalized into two main groups. This is an imitation of transactions (the so-called illegal transactions) with shares, as well as the commission of illegal actions with the register of shareholders.

As a result of the implementation of the first option, the owner is deprived of the right to own shares without taking any actions to transfer them and receives information about changes in the register of shareholders after a long time. During this time, the subject of absorption manages to carry out transactions. Stolen shares are mixed with shares acquired legally and resold to bona fide buyers.

The second method of stealing shares is applied to corporations that maintain a register of shareholders without involving specialized organizations. In this case, the level of security is low. In case of registrar disloyalty, the subject of absorption can apply this method. The purpose of illegal actions with the registry is to write off shares from the personal accounts of some individuals and transfer them to the accounts of others without a proper transfer order [6, p. 81-82].

2.2. Influence on decisions of state bodies.

The algorithm for the implementation of this takeover method is as follows:

- purchase of shares from minority shareholders (or theft of shares);

- initiation of criminal cases against controlling shareholders, members of the board of directors, managers;

- fixing the rights to the assets of the target corporation through decisions of the courts (registration authorities); 
- purchase of other shares of the target corporation;

- carrying out the takeover.

That is, the takeover entity, through the actions of corrupt officials (judges), implements the takeover, forcing the controlling shareholder to sell its shares [11].

Also, based on court rulings on securing a lawsuit, an arrest may be made on all significant assets of the target company, as well as a ban on management to enter into transactions. Under these conditions, it is impossible for current owners to withdraw assets or burden them with significant obligations.

If the takeover entity does not have enough resources to obtain the necessary court decision, the seizure of assets can be carried out as part of the criminal process on the basis of the actions of the inquiry officer, investigator or prosecutor during the investigation of criminal cases.

An implementation option for this takeover method is to transfer the registry to another registrar. This is based on the decisions of various courts to take measures to secure a claim. After this, the shareholding owned by the owner is stolen and resold to bona fide buyers [2].

\section{Discussion}

Based on the practice of acquiring corporate control in Russia, the takeover process is advisable to reflect the through three stages (picture 3).

1. Determination of the takeover motive.

There are many motives for the absorption. Individuals may seek to strengthen their influence in the corporation, the acquisition may be motivated by the acquisition of the right to use and disposal of its resources. The main motives for legal entities are entering new markets, increasing market share, obtaining contracts, tax benefits, increasing financial stability, diversification, acquiring product chains and others $[12 ; 13]$.

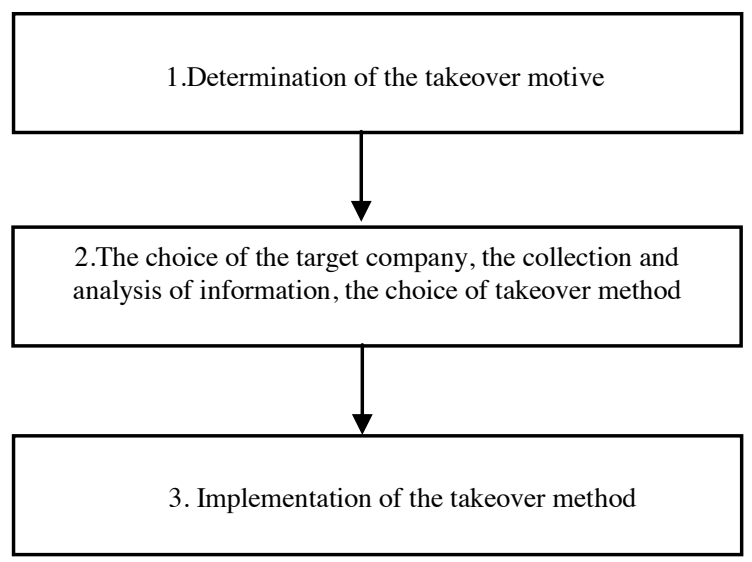

Fig. 3. Takeover process

Source: Own processing.

When a takeover motive is determined, the takeover entity searches for a suitable target company.

2. The choice of the target company, the collection and analysis of information, the choice of takeover method. 
At this stage, the subject determines the appropriateness of the takeover. The takeover subject may be interested in inefficient companies with low capitalization, corporations that have an unstable dividend history and infringe on the rights of shareholders, in which corporate conflicts exist.

At this stage, the following information about the target company is analyzed:

- corporate information (history of privatization (creation) of the company; information on the degree of dispersion of share capital; composition of owners; information from the charter documents, regulations; reports and minutes of general meetings of shareholders; minutes of meetings of the board of directors (supervisory board), executive collegial body; information about activities of branches, subsidiaries and affiliates);

- information on financial and economic activities (information on receivables and payables; information on the availability of liquid assets; quarterly reports; balance sheets; information on tax history; features of interaction with partners, creditors, suppliers, consumers);

- information on shareholders (participants) and the management staff (including information on the informal interests of managers and shareholders, especially relationships, information on leaders, conflict history) [2; 5].

Also, the takeover entity may be interested in analyzing similar information about the key stakeholders of the target company.

After analyzing the information, the subject of absorption reveals the degree of difficulty of absorption and selects the method of absorption [2].

3. Implementation of the takeover method.

Many Russian scientists have studied the actions that the takeover subject performs in the takeover process. Radygin A.D. and Etnov R.M. distinguish six groups of takeover methods:

- purchase of shares from employees, investment institutions, brokers, banks in the secondary market,

- voluntary or administrative-compulsory entry into holdings,

- the purchase of assets that are liquidated in the bankruptcy process,

- purchase and transformation of debts into property and equity participation;

- the use of court decisions (for recognition of previously completed transactions (issues of securities) invalid;

- initiation of court orders, including falsification of court decisions [14; 7, p. 57-58].

Markov P.A. identifies several of the most common forms (methods) of absorption:

- acquisition of a controlling stake,

- abuse of shareholder rights,

- manipulation of preferred shares,

- "erosion" of shares (by issuing during the arrest of shares of the main shareholder),

- purchase of debt instruments,

- falsification of the transfer order, which is submitted to the registrar, as well as decisions of general meetings of shareholders;

- purchase of small blocks of shares,

- use of the "parallel" registry [15, p. 46-47].

Studying acquisition strategies, M. Besedin identifies two absorption methods: bankruptcy; the acquisition of shares (shares in the authorized capital) guaranteeing corporate control [16].

There are other classifications of absorption methods that are characteristic of Russian practice:

- the acquisition of small blocks of shares,

- creation of conditions for bankruptcy of the target company,

- challenging ownership of strategically important assets, 
- actions aimed at reducing the value of the corporation and the subsequent acquisition of its assets;

- bribery of managers of the target company [4, p. 28].

Gomtsyan S.V. offers its own classification of takeover methods: purchase of votes, purchase of assets, direct purchase of shares, reorganization [1, p. 10]. below:

The three methods of acquiring the companies that are most widely used are presented

- establishing control over the executive body;

- purchase of a controlling stake;

- initiation of bankruptcy followed by the purchase of assets [3].

Because a typical takeover process consists of three stages, it is necessary to build protection against such processes relative to these stages. Different types of protection may apply in different countries, and this is due to differences in legal systems. However, the general logic of protection, and this applies to a company from any country, may be identical, namely:

- organization of information influence on the takeover subject in order to cause it to refuse to acquire control over the company (the first level of protection against takeover);

- managing the loyalty of stakeholders in order to organize long-term mutually beneficial interaction between them and the company (the second level of protection against takeover);

- creating procedural barriers in the takeover process in order to prevent the company's corporate governance system from making decisions that contribute to the takeover (the third level of protection against takeover).

\section{Conclusion}

The article presents a classification of the takeover methods, which differs from the existing classifications by differentiating the takeover methods according to the criterion "takeover tool used by the takeover initiator", the application of which allows the target company to choose the most appropriate and effective protective measures in a particular situation and thereby avoid some corporate conflicts. It was revealed that the takeover entity can perform various actions to gain control over the corporation's activities, eroding corporate ownership, using corporate conflicts, especially corporate relations in a particular company. However, as already noted, even a $100 \%$ share in the company capital does not always guarantee control over the corporation if the resource base of the company includes more valuable resources. Then the owners of these resources control the company. This is due to the fact that property rights are not clearly defined.

\section{References}

1. S. V. Gomtsyan. Takeover rules for joint-stock companies: comparative legal analysis/ Gomtsyan Suren vardanovich / / volters kluver 136 p. (2010)

2. Yu. V. Koneva. Unfriendly acquisitions and economic security of the enterprise. Legal guide of the head. [online], Available at: http://www.klerk.ru/law/articles/59089 (2006)

3. A. Molotnikov. Takeover of companies: an overview of methods and tools. [online], Available at: http://www.lin.ru/document.htm?id=1249703346338427714 (2001)

4. L. L. Nikitin, D. V. Nurzhinsky, The strategy and tactics of takeover defense. Mergers and Acquisitions. (2), 28-34 (2003) 
5. V. Pankratiev. Protection from hostile takeover. Business Entropy. [online], Available at: http://bizentropy.biz/articles/167-zashhita-ot-vrazhdebnogo-pogloshheniyaokonchanie.html

6. A. D. Osinovsky. Shareholder vs. joint-stock company. $2^{\text {nd }}$ ed, 384 p. (2006)

7. A. D. Radygin, R. M. Etnov. Problems of mergers and acquisitions in the corporate sector. 154 p. (2002).

8. V. Dominyak. Organizational loyalty: basic approaches. [online], Available at: http://dominiak.ru/publ/publ15.html

9. S. S. Baranskaya. Psychological factors of organizational loyalty. 24 p. (2012)

10. K. V. Uskov. Managing the loyalty of company participants in the aspect of protection from absorption. Vestnik universiteta (GUU) (1), 210-214 (2014)

11. The typical scheme of raiders ' seizure. [online], Available at: http://zahvaty.net/tipovaya-sxema-rejderskogo-zaxvata.html/2 (2010)

12. V. G. Antonov, O. Yu. Kirillova, M. V Samosudov, H. P. Kharchilava. Corporate management: Textbook for students of the specialty "Organization Management". State University of Management, Institute of Marketing of GUU. 287 p. (2010)

13. A. Ya. Cherenkov. Reasons and motives of corporate mergers and acquisitions. Financial research (14) [online], Available at: http://finis.rsue.ru/2007-1/Cher.pdf (2007)

14. E. S. Demidova. Features of hostile takeovers in the corporate sectors of the Russian Federation and the European Union and the problem of their regulation. [online], Available

at: http://elibrary.finec.ru/materials_files/izv/IzvSPbUEF2007_1_c157_161_s.pdf (2007)

15. P. A. Markov. Hostile takeover. Theory, practice, legal regulation: monograph. $96 \mathrm{p}$. (2010)

16. M. Yu. Besedin. Mechanism for ensuring economic security of economic entities from unfriendly acquisitions. 177 p. (2007)

17. K. G. Arutyunova. Ways to protect against "unfriendly acquisitions" in the civil law of Russia and the United States of America. 222 p. (2010)

18. D. V. Burykin. Unfriendly acquisitions as a threat to the economic security of jointstock companies. 216 p. (2006)

19. M. G. Iontsev. Corporate takeovers: mergers, acquisitions, greenmail. 224 p. (2006)

20. N. And. Krichevsky. Raiding: the portrait of a phenomenon. [online], Available at: http://www.ng.ru/ideas/2007-10-12/11_reiders.html (2007)

21. S. V. Savchuk. Analysis of the main motives of mergers and acquisitions. Management in Russia and abroad (5) [online], Available at: http://www.cfin.ru/press/management/2001-5/04.shtml (2001)

22. N. S. Sogrina. Features of unfriendly acquisitions (raiding) in the transformed economy. 189 p. (2010)

23. L. A. Trifonova. Formation of a strategy for protecting joint-stock companies from unfriendly takeover. 161 p. (2008) 